The BDJ News section accepts items that include general news, latest research and diary events that interest our readers. Press releases or articles may be edited, and should include a colour photograph if possible. Please direct your correspondence to the News Editor, Arveen Bajaj at the BDJ, The Macmillan Building, 4 Crinan Street, London N19XW or by email to bdj@bda.org

\section{HIV resource pack launched}

The National AIDS Trust (NAT) has produced a new resource pack, HIV in Healthcare, aimed at helping healthcare professionals treat people living with HIV fairly and equally. NAT called for the NHS to adopt proactive policies to prevent discrimination against people living with HIV earlier this month.

Aimed at those who do not directly work in sexual health, including GP practices and dentists, it has been endorsed by the RCN, RCGP and BDA. The resource pack raises awareness of discriminatory practices and provides advice and practical tools to help healthcare workers address and avoid stigmatising behaviour towards people living with HIV, or associated with HIV through a partner or family member.

Its recommendations include providing training for healthcare staff on HIV issues including best practice for avoiding occupational HIV transmission, adopting guidelines for fair and equal treatment of HIV positive patients, displaying antidiscrimination posters in staff areas and waiting rooms

For more information or to order a copy call the National AIDS Trust on 02078146767.

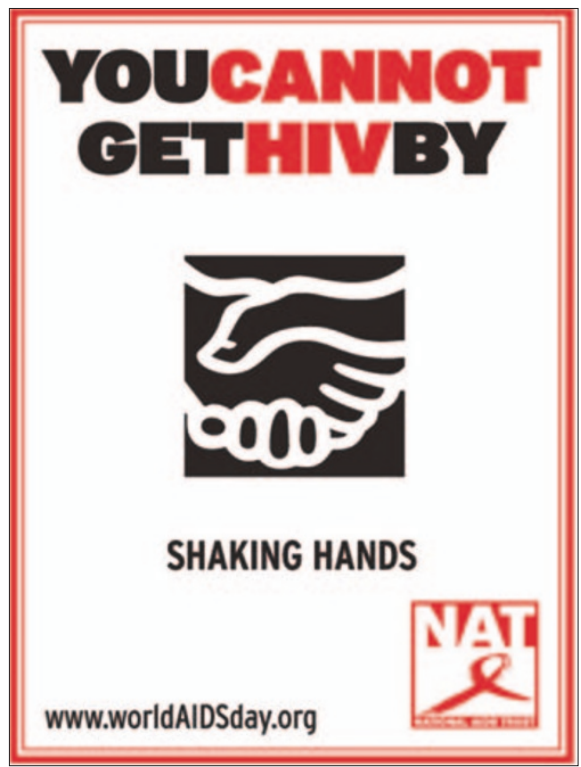

\section{Student achievements}

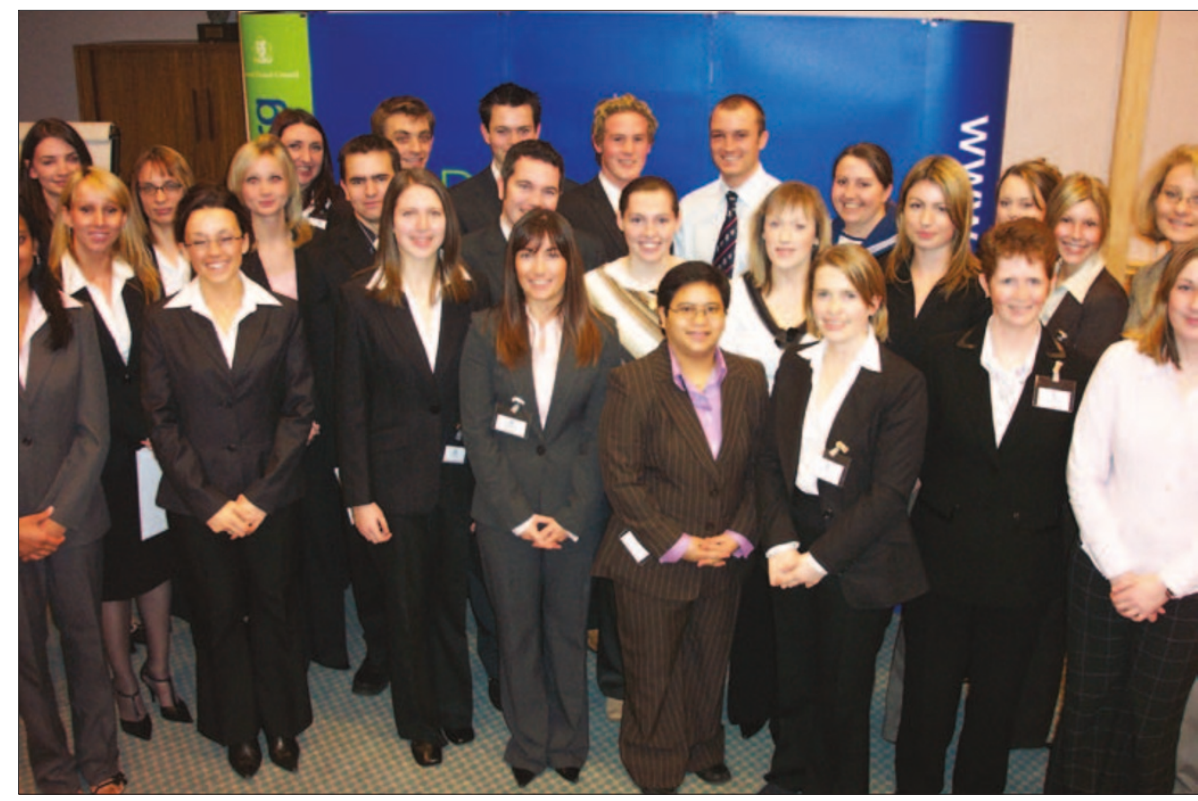

The GDC recently announced this year's winners of the GDC Prize for Professionalism award. The annual prize recognises the achievements of student dental professionals in the UK. It is awarded to students who have demonstrated professionalism in areas such as patient care, clinical governance, team working, communication skills, reliability, integrity and knowledge.

All UK dental schools, schools of dental hygiene and schools of dental therapy with undergraduates were invited to pick a winner each from among their students.

The winners received their prize money and certificates at a special award ceremony at the GDC in December. The GDC Prize for Professionalism was introduced last year and is sponsored by the GDC Charitable Trust.

Winning dental students receive a prize of $€ 250$; dental therapy students receive $€ 150$ and dental hygiene students $€ 100$ (the prize money corresponds to the length of their study programmes). Where a school runs programmes for dentists, dental therapists and dental hygienists, nominations were invited from all programmes.

\section{Visiting Professor appointed}

Professor David Thomas has recently been appointed Visiting Professor at the School of Health Sciences at Staffordshire University. He spent much of his career as a GDP working in the West Midlands in NHS dentistry, and currently his main interests are in the business side and management of general dental practice.

Professor Thomas is also Honorary Chair at Wolverhampton University, Postgraduate Tutor for Birmingham University and was given responsibility for progressing FDS by Assessment, which was developed by Professor Trevor Burke at The Royal College of Surgeons in Edinburgh.

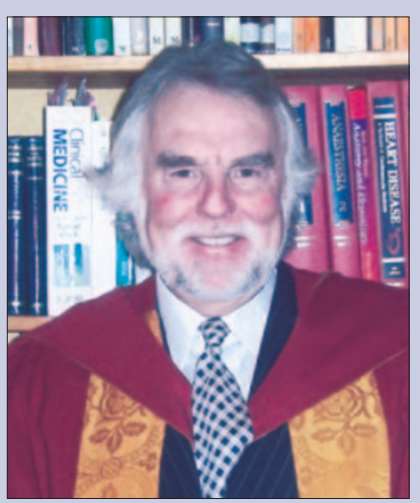




\section{DIARY}

January 2005

OSAP 4th Annual Intermediate-Level

Infection Control and Occupational Safety and Health Course

Date: 24-27.01.04

Venue: Hyatt Regency Atlanta, Georgia

Tel: 1-800-298-OSAP (6727)

www.osap.org.

International Dental Foundation 54th

International Alpine Dental Conference

Date: 29.01.05-05.02.05

Venue: Hotel Annapurna, Courcheval

1850, France

Contact: Robert Wallace

Tel: +44 (0) 2072350788

Fax: +44 (0) 2072350767

Email: idf@idfdentalconference.com

www.idfdentalconference.com

\section{March 2005}

83rd General Session \& Exhibition of the IADR, 34th Annual Meeting of the AADR, 29th Annual Meeting of the CADR

Date: 9-12.03.05

Venue: Baltimore Convention Centre www.dentalresearch.org

\section{April 2005}

Academy of Laser Dentistry Source 2005:

Lasers in Dentistry

Date: 6-9.04.05

Venue: New Orleans Marriott Hotel, New

Orleans, Louisiana, USA

Tel: 1-877-527-3776

Email:memberservices@

laserdentistry.org

www.source2005.org

\section{Missing person}

Devon \& Cornwall Constabulary are requesting the help of dentists in a missing person's enquiry. Julie Michelle Crocker was last seen on 21st September 2004 when she left home to attend an appointment at Derriford Hospital in Plymouth for an X-ray of her teeth. It is believed that she left the house at around $14.00 \mathrm{hrs}$. As she was undergoing dental treatment at the time of her disappearance, the investigating team believe that if she were alive she would want to continue that treatment and would need to register with a dentist in the area that she was residing in.

She is white, 41 years old, approximately 5 feet tall, of a thin/slim build, with dark very long hair, brown eyes and a fair complexion.

Anyone who can help with this enquiry should contact DS Mick Woodland, MIR, Crownhill Police Station, Plymouth. PL6 5HT, telephone number 01752751513.
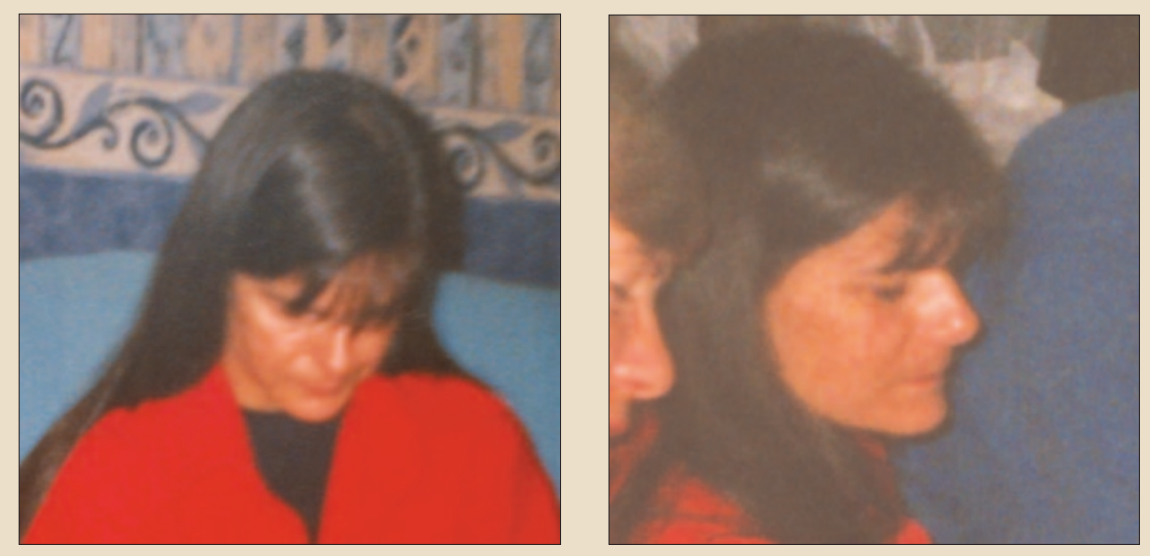

\section{Election hopes}

An NHS dentist has been named the Liberal Democrat's Gainsborough constituency party political candidate, and will be fighting in the next general election.

Dr Adrian Heath who practices at Oasis Dental Care in Lincoln, is also a West Lindsey District Councillor for Cherry Willingham and Reepham and was former Vice-Chairman of Environmental Services.

He studied dentistry at Newcastle Dental School and qualified in 1995. Previously to this he studied at King's College, University of London and had worked in clinical biochemistry in the NHS.

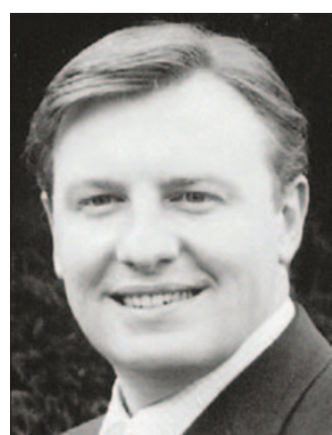




\section{Expanding work in developing world}

Dentists' Provident Society recently made their annual donation of $£ 6,000$ to the oral health charity Dentaid. With dental caries now recognised by the World Health Organisation as the world's most common disease, Dentaid is working to expand its well established equipment operation, which has sent over 120 surgeries to 43 countries, into areas of prevention and education. Having built a successful operation providing equipment which now relieves the dental pain of over 600,000 people annually, the work the charity began last year could help prevent future dental pain for many millions more worldwide in the years to come.

After introducing a new volunteer programme in Tanzania, the charity will pilot programmes to develop culturally appropriate oral health education materials, fluoride toothpaste dispensing, engineer training and supervised tooth brushing during 2005. To find out more about Dentaid's work, please visit the website: www.dentaid.org.

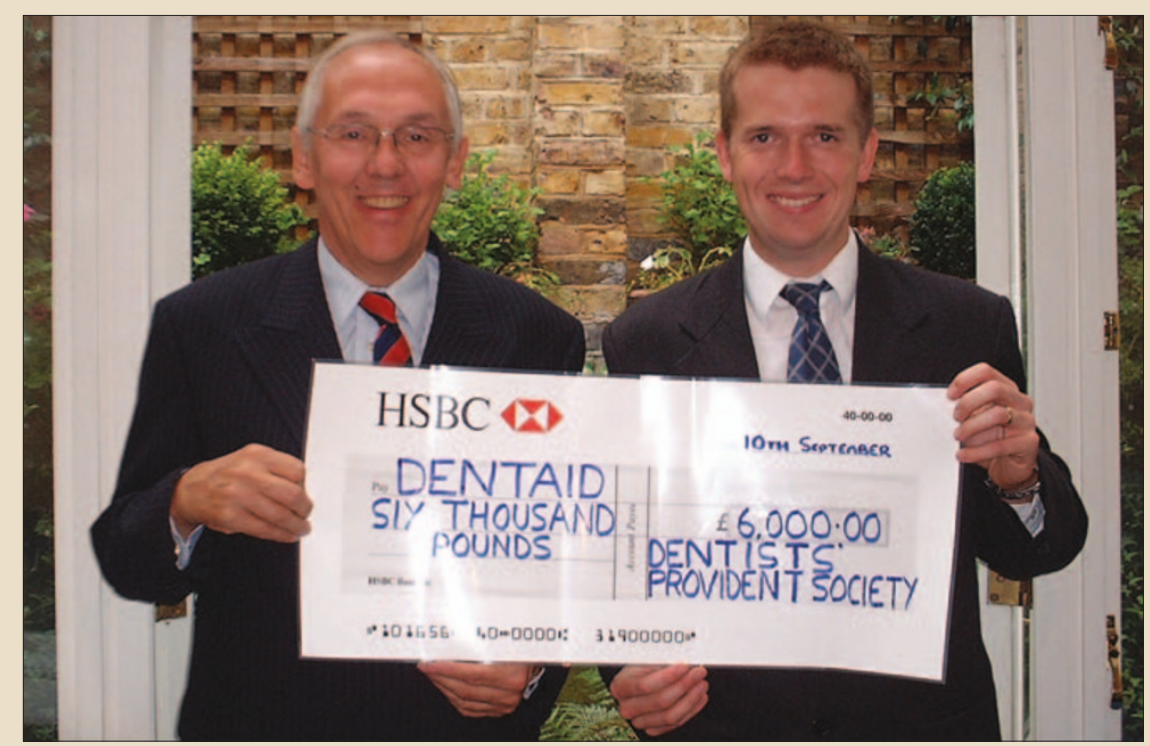

lan Passey of Dentists' Provident Society (left) hands the cheque to Luke Wordley of Dentaid

\section{First for region}

The dental suite in Northampton became the first dental practice in Northamptonshire to achieve the Investor in People award.

This was presented to

Mr.Qureshi and his staff by Mike

Howlett and Janet Moody of

Northants Business Link. The practice believes that the liP training has boosted its

confidence in offering these services.

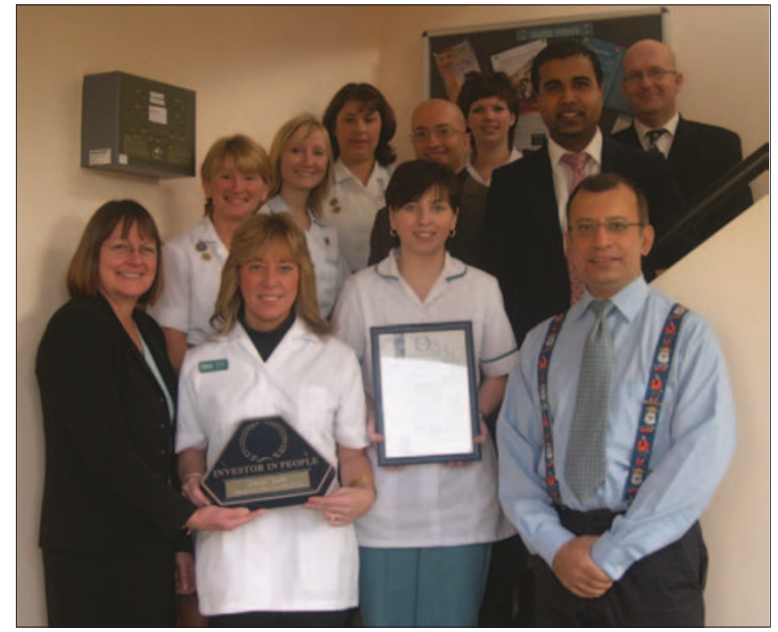

\section{Notification}

We are sorry to announce that we have been informed of the death of Michael Robert Kirkland who died on 14th December 2004, aged 81. An obituary will appear in a future issue of the $B D J$. 